Jurnal Matematika Vol. 10 No. 2, Desember 2020 - pp. 135-145

ISSN: $1693-1394$

Article DOI: https://doi.org/10.24843/JMAT.2020.v10.i02.p130

\title{
Memodelkan Impor Beras Menggunakan Regresi Data Panel
}

\author{
Eka N Kencana ${ }^{14 a \S}$, Darma Arnawa ${ }^{2 b}$, Ketut Jayanegara ${ }^{3 c}$ \\ 1,2,3 Program Studi Matematika, Universitas Udayana, Jimbaran-Badung 80361, ID \\ ${ }^{4}$ Pusat Unggulan Pariwisata, Universitas Udayana, Denpasar 80234, ID \\ E-mail: ${ }^{a}$ i.putu.enk@unud.ac.id, ${ }^{b}$ darmaarnawa11@gmail.com, ${ }^{c}$ ktjayanegara@unud.ac.id \\ ${ }^{\S}$ Penulis Korespondensi
}

Abstract Rice is one of the world's most important commodities. The Food and Agricultural Organizations estimates about 90 percent of the world's rice is produced by countries in the Asian continent with the rice production centers located in the ASEAN region. As an agricultural country, Indonesia is ranked third in the world rice producers after China and India, and in the first rank of ASEAN rice producers. However, Indonesia along with other producing countries in ASEAN also import rice. This article aims to model rice imports from 5 ASEAN countries. Using data from FAO for the period 2009-2018, 3 types of Panel Data Regression models were applied to model rice imports. The results of the analysis show Random Effect Model (REM) is the most appropriate model for rice imports in 5 ASEAN countries with the difference for two consecutive years import, consumption, and rice production was used as explanatory variables .

Keywords: import, panel data, random effect, regression, rice.

Abstrak Beras merupakan salah satu komoditas pangan terpenting dunia. Data Food and Agricultural Organizations (FAO) memperkirakan sekitar 90 persen beras dunia dihasilkan negara-negara di Benua Asia dengan pusat produksi padi Asia terletak di Kawasan ASEAN. Sebagai negara agraris, Indonesia menduduki peringkat ketiga produsen padi dunia setelah Tiongkok dan India, dan peringkat pertama produsen padi ASEAN. Meski demikian, Indonesia bersama negara-negara produsen lain di ASEAN juga melakukan impor beras. Artikel ini bertujuan memodelkan impor beras 5 negara ASEAN. Menggunakan data komoditas beras dari FAO pada periode tahun 2009-2018, 3 jenis model Regresi Data Panel diaplikasikan untuk memodelkan impor beras. Hasil analisis menunjukkan Random Effect Model (REM) merupakan model terlayak pada impor beras 5 negara ASEAN dengan perbedaan jumlah impor pada 2 tahun berturutan, konsumsi, dan produksi beras sebagai variabel-variabel penjelas.

Kata kunci: beras, data panel, impor, random effect, regresi. 


\section{Pendahuluan}

Sebagai tiga besar produsen beras Asia setelah Tiongkok (Daratan) dan India, Food and Agricultural Organization (FAO) menunjukkan rata-rata pertumbuhan produksi beras Indonesia pada periode tahun 2010 - 2019 bernilai negatif, yaitu -0, 86 per tahun (FAO, 2020). Pada tahun 2010 produksi gabah kering giling (GKG) Indonesia tercatat 59,3 juta ton, menurun menjadi 54,6 juta ton pada tahun 2019. Beberapa penyebab menurunnya produksi GKG pada tahun 2019 adalah faktor cuaca (kemarau), gagal panen (puso), dan awal masa tanam padi yang terlambat dari awal masa tanam biasanya (Lovitawati, 2020). Perkembangan produksi GKG dari lima besar produsen padi Asia ditunjukkan pada gambar 1 .

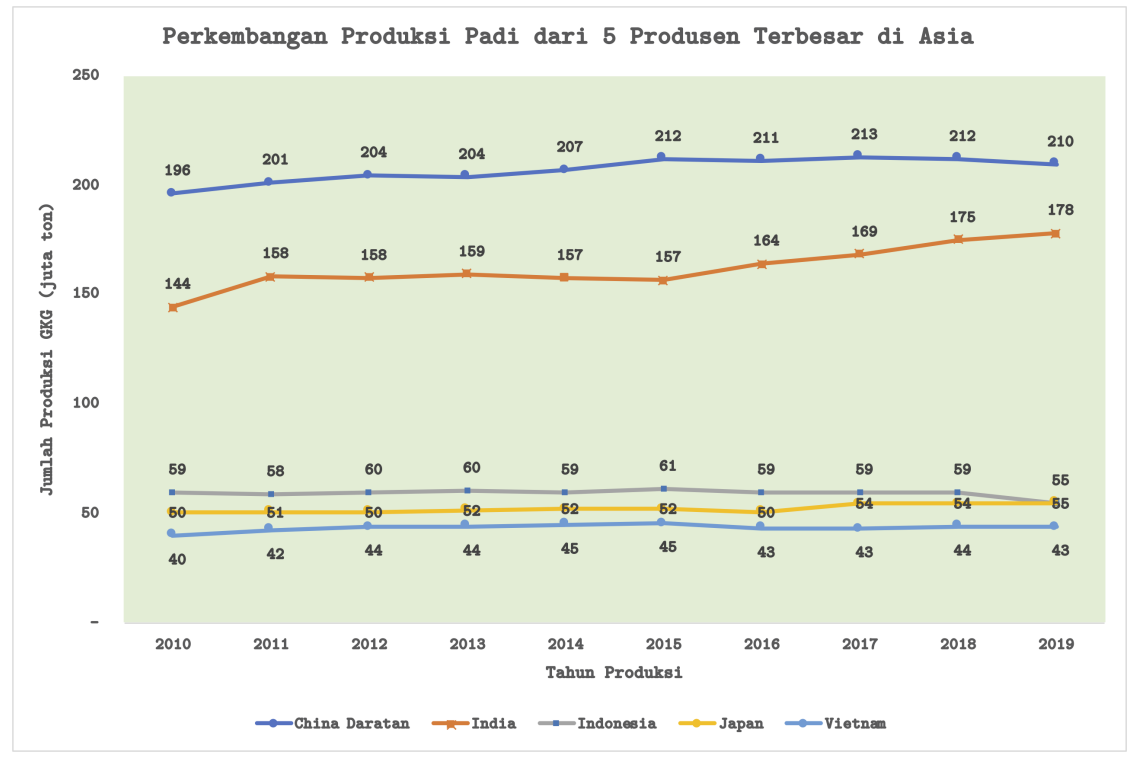

Gambar 1. Perkembangan Produksi GKG 5 Negara Asia

Meskipun Indonesia menduduki peringkat ketiga sebagai produsen padi di Asia, bahkan di dunia; mempertimbangkan jumlah penduduk Indonesia berada pada peringkat keempat dunia setelah Tiongkok, India, dan Amerika Serikat dengan jumlah penduduk Indonesia tahun 2019 tercatat sekitar 270 juta jiwa (Badan Pusat Statistik, 2020), Indonesia juga merupakan negara pengimpor beras dominan. BPS Indonesia mencatat pada periode tahun 2010-2018, Indonesia melakukan impor beras rata-rata per tahun sebesar 1,2 juta ton dengan impor pada tahun 2018 tercatat 2,2 juta ton. Bila dibandingkan dengan ekspor beras Indonesia pada tahun 2018 sebesar 3196 ton, maka secara empirik terlihat meskipun menduduki peringkat ketiga sebagai produsen beras Indonesia merupakan salah satu negara pengimpor beras terbesar.

Selain disebabkan oleh tidak tercukupinya produksi beras dalam negeri untuk konsumsi domestik, impor beras oleh beberapa negara produsen juga dilakukan karena adanya disparitas harga di dalam dengan luar negeri. Sebagai salah satu produk 
pangan penting, harga beras dunia cenderung bersifat fluktuatif yang berpengaruh terhadap volume ekspor dan/atau impor suatu negara. Sebagai dampak dari disparitas harga dan ketaksesuaian antara demand dengan supply beras domestik, maka sejumlah negara melakukan impor dan/atau ekspor beras.

Gambar 2 menunjukkan perkembangan produksi dan konsumsi beras di lima negara produsen padi yang tergabung dalam Association of South East Asian Nations (ASEAN). Pada gambar terlihat dengan jelas, konsumsi beras Indonesia melebihi jumlah produksinya pada dua tahun amatan. Dari kelima negara ASEAN pada gambar 2, Indonesia dan Philippines merupakan negara-negara pengimpor neto, sedangkan Thailand, Vietnam, dan Myanmar merupakan negara-negara pengekspor neto beras pada periode tahun 2010-2018. Mencermati impor beras merupakan variabel respon yang dipengaruhi oleh produksi dan konsumsi domestik (Suwandi, 2017, hal. 6) serta disparitas harga domestik dengan harga internasional, maka kebijakan impor beras di kelima negara ASEAN di atas menjadi sebuah kajian menarik. Artikel ini ditujukan untuk mengetahui prilaku impor beras di lima besar produsen beras negara-negara ASEAN yaitu Indonesia, Thailand, Vietnam, Myanmar, dan Philippines. Model persamaan regresi data panel (RDP) (panel data regression) diaplikasikan untuk tujuan tersebut.

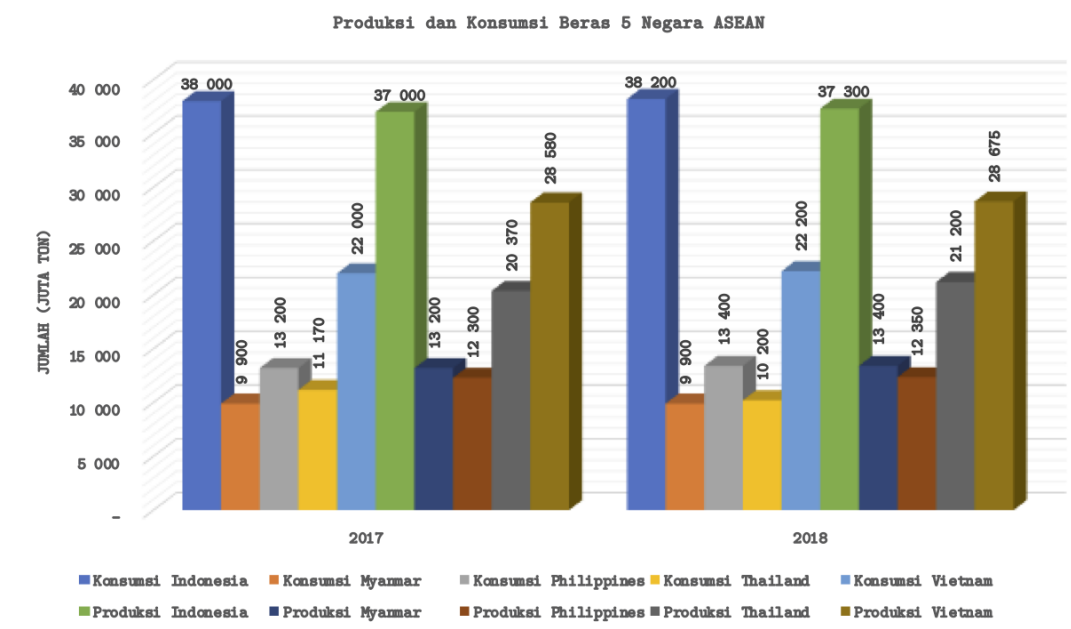

Gambar 2. Perkembangan Produksi \& Konsumsi Beras 5 Negara ASEAN

Memodelkan impor beras Indonesia telah dilakukan sejumlah peneliti dengan variabel bebas dan teknik pemodelan bervariasi. Syamsuddin et al. (2013) yang memodelkan impor beras Indonesia pada periode tahun 1982-2011 dengan analisis regresi linier berganda memperoleh harga beras domestik, kurs, dan Produk Domestik Bruto (PDB) sebagai variabel-variabel bebas mampu menjelaskan variansi impor beras sebesar 42,5 persen dan kurs tidak terbukti memiliki pengaruh nyata terhadap impor beras Indonesia. Pendekatan berbeda digunakan Darwanto and Rahayu (2008) untuk memodelkan secara dinamis impor beras Indonesia pada periode 
1969-2004. Menggunakan Error Component Model/ECM dan Engle-Granger Causality, para penulis memperoleh impor pada tahun ke- $t$ dipengaruhi oleh impor pada tahun $t-1$, dan dalam jangka panjang juga disertai dengan adanya pengaruh dari pendapatan per kapita penduduk.

Terkait dengan RDP, menurut Park (2011) data panel merupakan data yang menggabungkan unit amatan (cross-sectional) dengan unit berkala (time series) dan membentuk data yang bersifat longitudinal, sebuah unit amatan memiliki lebih dari satu unit berkala. Salah satu keunggulan dari data longitudinal adalah dimungkinkannya eksplorasi yang lebih komprehensif dibandingkan dengan data cross-section atau data berkala (Kennedy, 2008) melalui meningkatnya variansi informasi yang tersedia, kolinearitas antarvariabel yang bisa diminimumkan, dan meningkatnya efisiensi analisis dengan bertambahnya derajat bebas dari galat model (Baltagi, 2005, p. 5). Baltagi (2005) menyatakan model umum RDP seperti persamaan (1) :

$$
y_{i t}=\alpha+\mathbf{X}_{i t}^{\top} \beta+u_{i t} \quad i=1, \cdots, N ; \quad t=1, \cdots, T
$$

dengan $i$ menyatakan unit cross-section dan $t$ menyatakan unit berkala (runtun waktu); $\alpha$ merupakan intersep model; $\beta$ merupakan vektor berukuran $K \times 1$ dengan $K$ menunjukkan jumlah variabel penjelas; dan $u_{i t}$ merupakan komponen galat yang tersusun dari $\mu_{i t}$ (efek spesifik individu atau waktu yang tak teramati) dan $v_{i t}$ sebagai sub-komponen sisaan. Komponen galat pada RDP bisa dinyatakan sebagai:

$$
u_{i t}=\mu_{i}+v_{i t}
$$

Pada umumnya, RDP dibedakan menjadi 2 kelompok (Baltagi, 2005; Park, 2011) yaitu (a) model yang menghipotesiskan intersep antarunit cross-sction atau antarunit watu bersifat tetap ( fixed), dan (b) model yang mengelaborasi adanya kemungkinan perbedaan acak (random) pada komponen galat menurut unit-unit amatan (crosscesction atau waktu). Lebih lanjut, mengacu kepada pengelompokan ini model RDP lazim dibedakan menjadi 3 sub-model yaitu:

1. Common Effect Model (CEM): merupakan model RDP yang mengasumsikan efek spesifik individu atau waktu ( $\mu_{i t}$ pada persamaan 1 ) tidak diperhitungkan pada model, sehingga CEM pada RDP bisa dinyatakan seperti persamaan (2)

$$
y_{i t}=\alpha+\mathbf{X}_{i t}^{\top} \beta+v_{i t} \quad i=1, \cdots, N ; \quad t=1, \cdots, T
$$

Pada CEM, teknik pendugaan parameter yang digunakan adalah Ordinary Least Squares (OLS) mempertimbangkan penduga yang diperoleh bersifat efisien dan tak bias (Baltagi, 2005; Kennedy, 2008).

2. Fixed Effect Model (FEM): pada FEM, penggunaan variabel dummy untuk membedakan intersep antarunit cross-section atau antarwaktu merupakan pen- 
ciri dari sub-model ini. Merujuk Gujarati and Porter (2009), pada analisis satu arah atau oneway dimana efek individu tidak berinteraksi dengan efek waktu, FEM bisa dibedakan menjadi FEM individu $\left(\mathrm{FEM}_{\mathrm{I}}\right)$ dan FEM waktu $\left(\mathrm{FEM}_{\mathrm{T}}\right)$ dengan formulasi kedua model mengikuti persamaan (3) dan (4):

$$
\begin{aligned}
& \mathrm{FEM}_{\mathrm{I}}: \quad y_{i t}=\sum_{j=1}^{N} \alpha_{j} D_{i t}^{j}+\mathbf{X}_{i t}^{\top} \beta+v_{i t} ; \quad v_{i t} \stackrel{\text { i.i.j. }}{\sim} N\left(0, \sigma_{v}^{2}\right) \\
& \mathrm{FEM}_{\mathrm{T}}: \quad y_{i t}=\sum_{j=1}^{T} \alpha_{j} D_{i t}^{j}+\mathbf{X}_{i t}^{\top} \beta+v_{i t} ; \quad v_{i t} \stackrel{\text { i.i.j. }}{\sim} N\left(0, \sigma_{v}^{2}\right)
\end{aligned}
$$

dengan $D_{i t}^{j}$ merupakan $j$ variabel dummy sesuai jumlah amatan cross-section atau amatan berkala. Pada FEM, teknik penduga parameter yang biasa diaplikasikan adalah Least Squares Dummy Variables (LSDV), 'within' estimation, dan 'between' estimation (Park, 2011).

3. Random Effect Model (REM): REM pada RDP digunakan untuk menghindari berkurangnya derajat bebas pada FEM yang disebabkan keberadaan $D_{i t}^{j}$. Hal ini dilakukan dengan mengasumsikan $\mu_{i}$ pada persamaan (1) sebagai variabel acak dengan kondisi $\mu_{i}$ saling bebas dengan $v_{i t}, \mu_{i} \sim \operatorname{IID}\left(0, \sigma_{\mu}^{2}\right)$, dan $v_{i t} \sim$ $\operatorname{IID}\left(0, \sigma_{v}^{2}\right)$ (Baltagi, 2005). Pada REM, formulasi model dapat ditulis mengikuti persamaan (5).

$$
y_{i t}=\left(\alpha+\mu_{i}\right)+\mathbf{X}_{i t}^{\top} \beta+v_{i t} \quad i=1, \cdots, N ; \quad t=1, \cdots, T
$$

Teknik pendugaan parameter pada REM yang digunakan adalah Generalized Least Squares (GLS) dengan beberapa variasinya seperti Feasible GLS, dan Estimated GLS (Park, 2011).

\section{Metode Penelitian}

Memodelkan prilaku impor beras dari 5 besar produsen beras negara ASEAN pada periode 2009-2018 dilakukan menggunakan data sekunder yang diunduh dari situs FAO (FAO, 2020). Model RDP dibangun dengan Jumlah Impor masing-masing negara merupakan variabel respon dan Jumlah Konsumsi, Jumlah Produksi, dan DIFF(Impor) dihitung sebagai Impor ${ }_{t}$ Impor $_{t-1}$; merupakan variabel-variabel penjelas pada model.

Ketiga model RDP seperti uraian sebelumnya dibentuk untuk menentukan model 'terbaik' dari prilaku impor beras 5 negara ASEAN. Model 'terbaik' ditentukan dengan memperhatikan nilai koefisien determinasi model $\left(R^{2}\right)$, penerimaan model berdasarkan uji-uji Statistika, dan kelayakan teoritis dari parameter-parameter pen- 
Eka N Kencana, Darma Arnawa, Ketut Jayanegara / Memodelkan Impor Beras ...

duga. Menggunakan R (R Core Team, 2020) dan plm package dari Croissant and Millo (2008) pembentukan model RDP pada artikel ini dilakukan mengikuti tahapan berikut:

1. Membentuk model impor beras menggunakan CEM, FEM, dan REM;

2. Memeriksa poolability data menggunakan Uji Chow;

3. Memeriksa signifikansi FEM dan REM, masing-masing menggunakan Uji F dan Uji Breusch-Pagan; dan

4. Memeriksa kelayakan FEM atau REM sebagai model RDP menggunakan Uji Hausman.

\section{$3 \quad$ Hasil Analisis \& Diskusi}

\subsection{Pembentukan Model-model Regresi Data Panel}

Common Effect Model (CEM)

Model impor beras 5 besar produsen beras ASEAN pada periode tahun 2009-2018 dengan common effect ditunjukkan pada Tabel 1 .

Tabel 1. Common Effect Model Impor Beras 5 Negara ASEAN

\begin{tabular}{lrrrrr}
\hline & Penduga & Simp. Baku & $t$-Hitung & Nilai $p$ & Keterangan \\
\hline Intersep Model & 597,443 & 185,574 & 3,219 & 0,003 & $* *$ \\
DIFF (Impor) & 0,428 & 0,122 & 3,510 & 0,001 & $* *$ \\
Konsumsi & 0,098 & 0,017 & 5,950 & 0,000 & $* *$ \\
Produksi & $-0,081$ & 0,018 & $-4,385$ & 0,000 & $* *$ \\
\hline & & & Statistik F $(3 ; 41)$ & 17,815 \\
& & Nilai $p$ & 0,000 \\
& & Nilai $\mathrm{R}^{2}(\%)$ & 56,588 \\
\hline
\end{tabular}

Sumber: Analisis Data (2020)

Tabel 1 menunjukkan CEM menghasilkan model RDP yang signifikan dengan nilai koefisien determinasi 56,59 persen. Selain itu, penduga DIFF(Impor) memiliki nilai terbesar dibandingkan 2 variabel penjelas lain. Hal ini sesuai dengan temuan riset Darwanto and Rahayu (2008). Koefisien bernilai negatif dari variabel produksi menjelaskan bila produksi padi meningkat maka impor menurun . Hal ini juga sejalan dengan pendapat Suwandi (2017). 
Jurnal Matematika Vol. 10 No. 2, Desember 2020 - pp. 135-145

ISSN: 1693-1394

Article DOI: https://doi.org/10.24843/JMAT.2020.v10.i02.p130

Fixed Effect Model (FEM)

Ringkasan FEM individu $\left(\mathrm{FEM}_{\mathrm{I}}\right)$ dan FEM waktu $\left(\mathrm{FEM}_{\mathrm{T}}\right)$ ditunjukkan pada Tabel 2 dan Tabel 3

Tabel 2. FEM Individual Impor Beras 5 Negara ASEAN

\begin{tabular}{|c|c|c|c|c|c|}
\hline & Penduga & Simp. Baku & $t$-Hitung & Nilai $p$ & Keterangan \\
\hline DIFF (Impor) & 0,470 & 0,077 & 6,091 & 0,000 & $* *$ \\
\hline Konsumsi & 0,016 & 0,082 & 0,190 & 0,851 & ns \\
\hline Produksi & $-0,029$ & 0,055 & $-0,525$ & 0,603 & $\mathrm{~ns}$ \\
\hline \multicolumn{6}{|l|}{ Intersep } \\
\hline Indonesia & 1891,40 & 2951,38 & 0,641 & 0,526 & ns \\
\hline Myanmar & 209,28 & 841,09 & 0,249 & 0,805 & $\mathrm{~ns}$ \\
\hline Philippines & 1533,42 & 999,52 & 1,534 & 0,134 & ns \\
\hline Thailand & 736,36 & 1079,30 & 0,682 & 0,499 & ns \\
\hline \multirow[t]{2}{*}{ Vietnam } & 802,89 & 1806,54 & 0,444 & 0,659 & ns \\
\hline & & & \multicolumn{2}{|c|}{ Nilai $\mathrm{R}^{2}(\%)$} & $\begin{array}{r}0,000 \\
50,384\end{array}$ \\
\hline
\end{tabular}

Sumber: Analisis Data (2020)

Tabel 3. FEM Waktu Impor Beras 5 Negara ASEAN

\begin{tabular}{lrrrrr}
\hline & Penduga & Simp. Baku & $t$-Hitung & Nilai $p$ & Keterangan \\
\hline DIFF (Impor) & 0,409 & 0,141 & 2,899 & 0,007 & $* *$ \\
Konsumsi & 0,010 & 0,018 & 5,678 & 0,000 & $* *$ \\
Produksi & $-0,082$ & 0,019 & $-4,182$ & 0,000 & $* *$ \\
\hline Intersep & & & & \\
2010 & 825,93 & 285,94 & 2,888 & 0,007 & $* *$ \\
2011 & 818,89 & 291,51 & 2,809 & 0,008 & $* *$ \\
2012 & 499,74 & 296,96 & 1,683 & 0,102 & ns \\
2013 & 508,85 & 292,67 & 1,739 & 0,091 & ns \\
2014 & 655,07 & 288,93 & 2,267 & 0,030 & $*$ \\
2015 & 455,00 & 288,33 & 1,578 & 0,124 & ns \\
2016 & 348,99 & 290,05 & 1,203 & 0,237 & ns \\
2017 & 609,83 & 298,43 & 2,044 & 0,049 & $*$ \\
2018 & 654,48 & 301,99 & 2,167 & 0,038 & $*$ \\
\hline & & & Nilai $p$ & 0,000 \\
& & & Nilai $\mathrm{R}^{2}(\%)$ & 58,385 \\
\hline
\end{tabular}

Sumber: Analisis Data (2020) 
Eka N Kencana, Darma Arnawa, Ketut Jayanegara / Memodelkan Impor Beras ...

Hasil analisis menunjukkan kedua FEM, FEM dan FEM T $_{\mathrm{T}}$ merupakan model-model yang signifikan masing-masing dengan nilai $\mathrm{R}^{2}$ sebesar 50,38 persen dan 58,39 persen. Pada FEM individual seluruh slope persamaan tidak signifikan, sedangkan pada FEM waktu terdapat 4 periode amatan (tahun 2012, 2013, 2015, dan 2016) tidak signifikan.

\section{Random Effect Model (REM)}

REM impor beras 5 besar produsen beras ASEAN pada periode tahun 2009-2018 diringkas pada Tabel 4 .

Tabel 4. Random Effect Model Impor Beras 5 Negara ASEAN

\begin{tabular}{|c|c|c|c|c|c|}
\hline & Penduga & Simp. Baku & $t$-Hitung & Nilai $p$ & Keterangan \\
\hline Intersep Model & 517,058 & 387,929 & 1,333 & 0,183 & ns \\
\hline DIFF (Impor) & 0,463 & 0,079 & 5,841 & 0,000 & ** \\
\hline Konsumsi & 0,082 & 0,031 & 2,611 & 0,009 & ** \\
\hline Produksi & $-0,062$ & 0,033 & $-1,845$ & 0,065 & ! \\
\hline \multicolumn{5}{|c|}{$\begin{array}{r}\text { Statistik } \chi_{(3)}^{2} \\
\text { Nilai } p\end{array}$} & $\begin{array}{r}42,210 \\
0,000 \\
50,727\end{array}$ \\
\hline
\end{tabular}

Sumber: Analisis Data (2020)

REM pada model RDP dari impor beras 5 negara ASEAN memperlihatkan ketiga variabel penjelas memiliki pengaruh nyata dengan pengaruh terbesar ditunjukkan oleh variabel jumlah impor setahun sebelumnya. Model signifikan pada taraf uji 1 persen dengan nilai $R^{2} 50,73$ persen.

\subsection{Kelayakan Model-model Regresi Data Panel}

Kelayakan empat model RDP yang dibentuk dilakukan melalui sejumlah uji, sebagai berikut:

Uji Chow: uji ini digunakan untuk memeriksa poolability data. Poolability berkaitan dengan dugaan parameter persamaan RDP (intersep dan slope) bernilai sama untuk masing-masing individu amatan (Baltagi, 2005: Croissant and Millo, 2008; Park, 2011). Menggunakan Uji Chow, poolability data diperiksa melalui hipotesis $\mathrm{H}_{0}: \beta_{i k}=\beta_{k} ; \forall i=1, \cdots, N$.

Pemeriksaan poolability dari CEM pada Tabel 1 menggunakan $\mathbf{R}$ memberikan hasil penolakan $\mathrm{H}_{0}$ dengan nilai $\mathrm{F}_{(16 ; 25)}=3,107$ dan nilai $p=0,005$. Penolakan $\mathrm{H}_{0}$ menunjukkan terdapat perbedaan parameter (pada unit individu atau pada 
unit waktu) sehingga CEM tidak tepat untuk digunakan sebagai model RDP dari impor beras yang dilakukan 5 produsen beras terbesar ASEAN.

Breusch-Pagan LM Test: uji ini ditujukan untuk memeriksa adanya perbedaan pengaruh dari unit individu atau unit berkala pada variabel respon. Mencermati terdapat 2 FEM yang dibangun (Tabel 2 dan Tabel 3), maka uji diaplikasikan untuk masing-masing FEM. Pada $\mathrm{FEM}_{\mathrm{I}}$ diperoleh nilai $\chi_{(1)}^{2}=60,419$ dengan nilai $p=0,000$; dan pada $\mathrm{FEM}_{\mathrm{T}}$ diperoleh nilai $\chi_{(1)}^{2}=1,214$ dengan nilai $p=0,271$. Statistik $\chi^{2}$ pada $\mathrm{FEM}_{\mathrm{I}}$ menunjukkan terdapat pengaruh signifikan dari variabel individual pada impor beras 5 negara ASEAN, sedangkan Statistik $\chi^{2}$ pada $\mathrm{FEM}_{\mathrm{T}}$ menunjukkan pengaruh waktu terbukti tidak nyata. Mencermati hal ini, maka $\mathrm{FEM}_{\mathrm{I}}$ layak digunakan sebagai model RDP dari impor beras 5 negara ASEAN.

Uji Hausman: uji ini digunakan untuk menentukan apakah FEM ataukah REM yang lebih layak digunakan pada model RDP. Pasangan hipotesis yang diperiksa pada uji ini dinyatakan sebagai:
$\mathbf{H}_{0}: E\left(v_{i t} \mid X_{i t}\right)=0 ; \quad$ (REM konsisten)
$\mathbf{H}_{1}: E\left(v_{i t} \mid X_{i t}\right) \neq 0 ; \quad$ (REM tidak konsisten)

Menggunakan phtest() dari plm package, pada komparasi REM dengan FEM $_{\mathrm{I}}$ diperoleh statistik $\chi_{(3)}^{2}=1,027$ dengan nilai $p=0,794$ yang menunjukkan $\mathrm{H}_{0}$ tidak bisa ditolak atau REM lebih layak digunakan dibandingkan dengan $\mathrm{FEM}_{\mathrm{I}}$.

\subsection{Diskusi}

Melalui serangkaian uji kelayakan model, diperoleh REM (Tabel 44) memiliki kriteria terlayak untuk memodelkan impor beras dari 5 produsen beras ASEAN. Pada periode tahun 2009-2018, impor beras pada tahun ke- $t$ oleh 5 negara ini secara signifikan dipengaruhi impor beras yang dilakukannya pada tahun ke- $t-1$ (Darwanto and Rahayu, 2008), disusul variabel penjelas konsumsi dan produksi beras di masing-masing negara. Pengaruh negatif dari produksi beras - meningkatnya produksi menyebabkan impor menurun, sejalan dengan pendapat Suwandi (2017); Namira et al. (2017).

Meskipun REM pada artikel ini memiliki nilai $\mathrm{R}^{2} \approx 50$ persen yang menunjukkan kontribusi ketiga variabel penjelas pada model, bila dibandingkan dengan nilai $\mathrm{R}^{2}$ yang diperoleh Namira et al. (2017) sebesar 83 persen menggunakan analisis regresi linear dengan 6 variabel penjelas, REM pada artikel ini terindikasi lebih efisien. Nilai $\mathrm{R}^{2}$ dari REM yang dibangun lebih besar bila dibandingkan dengan nilai yang diperoleh Syamsuddin et al. (2013) sebesar 42,5 persen dalam menganalisis impor beras di Indonesia menggunakan analisis regresi linear yang melibatkan variabelvariabel penjelas nilai beras domestik, nilai tukar rupiah, dan PDB. 
Terbatasnya koefisien determinasi yang dihasilkan REM pada artikel ini, selain disebabkan terbatasnya jumlah variabel penjelas, juga bisa disebabkan oleh tidak diperhitungkannya pengaruh ketetanggaan (neighbouring) dari 3 negara ASEAN yaitu Philippines, Thailand, dan Vietnam. Riset yang dilakukan Lasdiyanti et al. (2008) dalam memodelkan Indeks Pembangunan Manusia di Provinsi Bali menggunakan RDP dan RDP Spasial menunjukkan FEM yang mempertimbangkan keberadaan efek spasial mampu meningkatkan nilai $\mathrm{R}^{2}$ model sebesar 39 persen dibandingkan dengan FEM yang tidak memperhitungkan efek tersebut.

\section{Simpulan dan Rekomendasi}

\subsection{Simpulan}

Memodelkan impor beras yang dilakukan 5 besar produsen beras ASEAN menggunakan Regresi Data Panel, menyimpulkan:

1. Dari tiga bentuk umum model RDP yang dibangun, REM merupakan model terlayak. Pada REM, ketiga variabel penjelas pada model menunjukkan pengaruh-pengaruh yang signifikan dengan pengaruh dari produksi beras pada tahun berjalan mengurangi impor yang dilakukan kelima negara. Pengaruh dari 2 variabel penjelas lain bersifat negatif, di mana meningkatnya selisih impor pada 2 tahun yang berturutan serta bertambahnya produksi menyebabkan impor yang dilakukan kelima negara meningkat; dan

2. Tidak optimalnya nilai koefisien determinasi $\left(\mathrm{R}^{2}\right)$ model, selain disebabkan terbatasnya jumlah variabel penjelas diduga juga disebabkan oleh tidak terakomodirnya pengaruh spasial dari ketetanggaan 3 negara ASEAN yang dianalisis.

\subsection{Rekomendasi}

Berhubungan dengan limitasi dari simpulan artikel ini, dua rekomendasi untuk studi lanjutan diusulkan:

1. Melengkapi dan/atau menambah variabel penjelas pada model yang dirancang untuk meningkatkan manfaat interpretasi model. Misalnya, menyertakan disparitas harga beras domestik dengan harga beras di luar negeri akan memberik-

an informasi berharga mengenai value of money dari perdagangan internasional untuk komoditas beras; dan

2. Menyertakan adanya pengaruh spasial pada model menggunakan RDP Spasial sehingga kebermaknaan model bisa ditingkatkan. 
Jurnal Matematika Vol. 10 No. 2, Desember 2020 - pp. 135-145

ISSN: 1693-1394

Article DOI: https://doi.org/10.24843/JMAT.2020.v10.i02.p130

\section{Ucapan Terima Kasih}

Ucapan terima kasih disampaikan kepada Komang Gde Sukarsa, Putu Suciptawati dan Made Susilawati di Laboratorium Statistika PS. Matematika UNUD serta G.K. Gandhiadi di Laboratorium Komputasi PS. Matematika UNUD - yang memberikan masukan untuk penyempurnaan artikel ini.

\section{Referensi}

Badan Pusat Statistik (2020). Statistik Indonesia 2020. BPS Indonesia, Jakarta.

Baltagi, B. H. (2005). Econometric Analysis of Panel Data. John Wiley \& Sons, England, 3rd edition.

Croissant, Y. and Millo, G. (2008). Panel Data Econometrics in R: The plm Package. Journal of Statistical Software, 27(2):1-43.

Darwanto, D. H. and Rahayu, E. S. (2008). Analisis Faktor-faktor yang Mempengaruhi Impor Beras Indonesia. Caraka Tani, XXIII(1):1-8.

FAO (2020). Food and Agriculture Data. [Online; accessed 28 December 2020].

Gujarati, D. N. and Porter, D. C. (2009). Basics Econometrics. The McGrawHill/Irwin, New York, 5th edition.

Kennedy, P. (2008). A Guide to Econometrics. Wiley-Blackwell, Victoria, AU, 6th edition.

Lasdiyanti, M., Kencana, E. N., and Suciptawati, P. (2008). Modeling Human Development Index of Bali with Spatial Panel Data Regression. European Journal of Engineering Research and Science, 4(5):132-37.

Lovitawati, J. (2020). Produksi Beras Nasional Turun pada 2019. [Online; accessed 29 December 2020].

Namira, Y., Nuhung, I. A., and Najamudin, M. (2017). Analisis Faktor-faktor yang Mempengaruhi Impor Beras di Indonesia. Jurnal Agribisnis, 11(6):183-201.

Park, H. M. (2011). Practical Guides To Panel Data Modeling: A Step-by-step Analysis Using Stata. Graduate School of International Relations, International University of Japan, Niigata, Japan.

R Core Team (2020). R: A Language and Environment for Statistical Computing. $\mathrm{R}$ Foundation for Statistical Computing, Vienna, Austria.

Suwandi (2017). Outlook Tanaman Pangan dan Hortikultura. Pusat Data dan Sistem Informasi Pertanian, Sekretariat Jendral Kementerian Pertanian, Jakarta.

Syamsuddin, N., Hamzah, A., and Nasir, M. (2013). Analisis Faktor-faktor yang Mempengaruhi Impor Beras di Indonesia. Jurnal Ilmu Ekonomi, 1(3):58-70. 